\title{
Leucine-rich repeat kinase 2 and alpha-synuclein: intersecting pathways in the pathogenesis of Parkinson's disease?
}

\author{
Elisa Greggio, Marco Bisaglia, Laura Civiero, Luigi Bubacco*
}

\begin{abstract}
Although Parkinson's disease (PD) is generally a sporadic neurological disorder, the discovery of monogenic, hereditable forms of the disease has been crucial in delineating the molecular pathways that lead to this pathology. Genes responsible for familial PD can be ascribed to two categories based both on their mode of inheritance and their suggested biological function. Mutations in parkin, PINK1 and DJ-1 cause of recessive Parkinsonism, with a variable pathology often lacking the characteristic Lewy bodies (LBs) in the surviving neurons. Intriguingly, recent findings highlight a converging role of all these genes in mitochondria function, suggesting a common molecular pathway for recessive Parkinsonism. Mutations in a second group of genes, encoding alphasynuclein ( $\alpha$-syn) and LRRK2, are transmitted in a dominant fashion and generally lead to LB pathology, with $\alpha$-syn being the major component of these proteinaceous aggregates. In experimental systems, overexpression of mutant proteins is toxic, as predicted for dominant mutations, but the normal function of both proteins is still elusive. The fact that $\alpha$-syn is heavily phosphorylated in LBs and that LRRK2 is a protein kinase, suggests that a link, not necessarily direct, exists between the two. What are the experimental data supporting a common molecular pathway for dominant PD genes? Do $\alpha$-syn and LRRK2 target common molecules? Does LRRK2 act upstream of $\alpha$ syn? In this review we will try to address these of questions based on the recent findings available in the literature.
\end{abstract}

\section{Introduction}

Parkinson's disease (PD) is a common neurodegenerative disease historically classified as a sporadic disorder. The clinical phenotype of PD consists of motor dysfunctions including resting tremors, postural instability and bradykinesia. Non-motor manifestations such as autonomic and cognitive dysfunction are also recognized as part of the syndrome. Two histopathological features define the disease. First, there is a progressive degeneration of dopaminergic projections from the substantia nigra pars compacta $(\mathrm{SNpc})$ to the striatum. These neurons are pigmented as they contain cytoplasmic neuromelanin, which accumulates in an age-dependent manner. When the first motor symptoms appear, the $\mathrm{SNpc}$ is already severely depigmented with over $70 \%$ of dopamine-producing cells lost. A second neuropathological event is the deposition of proteinaceous inclusions

\footnotetext{
* Correspondence: luigi.bubacco@unipd.it

Department of Biology, University of Padova, Via U. Bassi 58/b, 35121, Padova, Italy
}

termed Lewy bodies (LBs) in the surviving neurons. LBs are predominantly made up of the small presynaptic protein $\alpha$-syn [1], which is used as a marker for the progression of the disease.

The discovery of monogenic forms of PD marked a revolution in our understanding of the molecular mechanisms underlying this pathology. The big advantage of studying a genetic disorder compared to a sporadic syndrome is that we can use engineered cellular and animal models carrying the mutant gene to define pathological pathways. In 1997, mutations in the gene $S N C A$, encoding $\alpha$-syn, were identified as cause of dominantly inherited PD [2]. Beta-sheet-rich fibrillar forms of $\alpha$-syn aggregates represent the main constituents of LBs in PD and several other LB diseases [1]. Recently, polymorphisms around SNCA have been associated with increased risk of sporadic PD, indicating that the gene is also an important risk factor for the disease $[3,4]$. After $S N C A$, a number of additional genes have been linked to PD. Mutations in three genes, coding for parkin, DJ-1 and PINK1, are the cause of recessive forms of 
parkinsonism [5-7]. Interestingly, the major common functional effects of all three genes relate to mitochondrial function and oxidative damage, suggesting a common pathway for recessive parkinsonism. In 2004, mutations in the gene coding for the protein Leucinerich repeat kinase 2 (LRRK2) were shown to cause an autosomal dominant form of PD $[8,9]$ with a clinical presentation and disease onset very similar to the sporadic disorder. Leucine-rich repeat kinase 2 mutations account for $1-40 \%$ of total PD cases depending on the population under study [10], suggesting that they are also a risk factor for the disease.

Because $\alpha$-syn and LRRK2 are implicated in both genetic and sporadic PD, understanding the physiological and pathological functions of these proteins may provide an excellent opportunity to gain insights into the sporadic disease, with obvious therapeutic implications.

In this review we will discuss some of the recent literature on the two genes that are known to cause dominantly inherited PD, namely Leucine-rich repeat kinase 2 and $S N C A$, focusing on the possible intersecting pathways between these two players.

\section{$\alpha$-Syn: physiological and pathological role}

The discovery of mutations in SNCA were the first evidence of a genetic cause for PD [2]. Three point mutations [2,11,12] as well as gene triplication [12] and duplication [13] have been linked to a form of parkinsonism similar to the sporadic syndrome. $\alpha$-Syn is a 140-amino acid protein enriched in the presynaptic terminals of neurons in the central nervous system [14], where it has been associated with a specific subpopulation of synaptic vesicles [15] and with the lipid rafts of the plasma membrane [16]. The N-terminal region of the protein contains a number of imperfect repeats, with the consensus motif KTKEGV, which strongly resembles that found in the amphipathic helices of the exchangeable apolipoproteins [17]. The central hydrophobic region of $\alpha$-syn, called NAC (non-amyloid component), has been suggested to be responsible for the aggregation process [18] while the acidic C-terminal region has been shown to regulate fibril formation [19] (figure 1A). Several studies suggest that $\alpha$-syn exists in equilibrium between a cytosolic unfolded conformation and a membrane-bound, alpha-helical structure [20,21]. Interaction of $\alpha$-syn with membranes has been extensively characterized in vitro using micelles and small unilamellar vescicles made of different phospholipids (see [22] for a review).

Although its precise function is still elusive, its subcellular localization within the nerve terminal and its ability to interact with membranes, suggest that $\alpha$-syn may play a role in regulating vesicle dynamics and trafficking at the presynaptic terminal and in brain lipid metabolism [23,24]. A recent study by Burrè and co-workers nicely demonstrated that $\alpha$-syn regulates the release of neurotrasmitters at the pre-synaptic terminal by

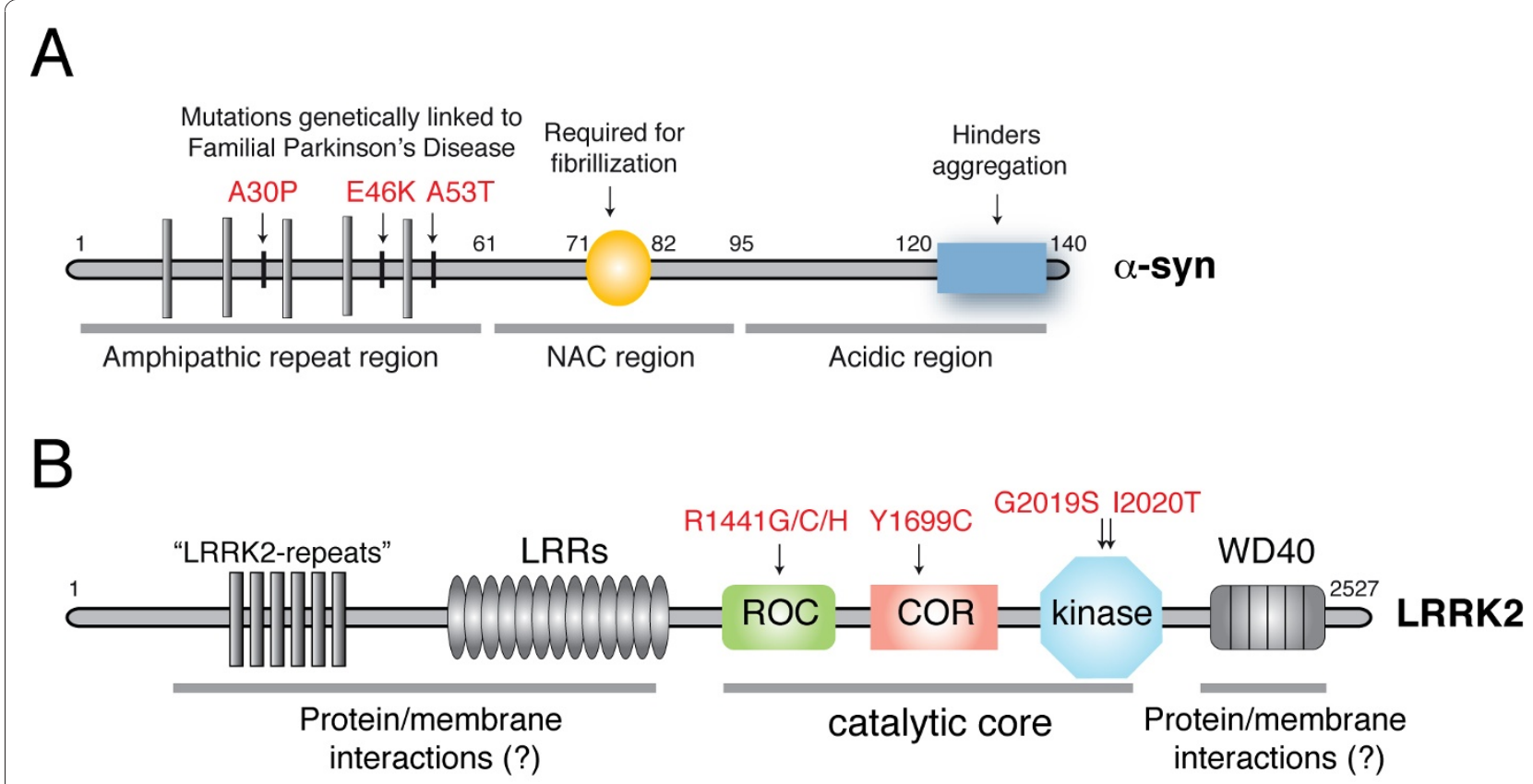

Figure 1 (A) Schematic of $\boldsymbol{\alpha}$-syn domains (NAC, non-amyloid $\boldsymbol{\beta}$ component). (B) Schematic of LRRK2 domains (LRRs, Leucine-rich repeats; ROC, Ras Of Complex proteins; COR, C-terminus Of ROC). 
promoting the assembly of the SNARE complex [25]. In addition, $\alpha$-syn seems to modulate intracellular DA concentration through interactions with proteins that regulate DA synthesis and uptake, such as tyrosine hydroxylase [26], the aromatic amino acid decarboxylase [27] and plasma membrane dopamine transporter [28]. Interestingly, $\alpha$-syn knock-out mice lack an obvious phenotype, suggesting that the protein does not play a crucial role in the development or neuronal maintenance [29-31]. Only a triple transgenic mouse lacking $\alpha-, \beta$-, and $\gamma$-syn shows alterations in synaptic structure and transmission, age-dependent neuronal dysfunction and diminished survival [32]. These observations indicate that $\alpha$-syn-induced neurodegeneration may not be due to a loss of function of the protein. In contrast to the minimal phenotype of $\alpha$-syn knockout mice, recent works have shown that the overexpression of $\alpha$-syn produces considerable toxicity by affecting synaptic transmission. The available evidence strongly suggests that inhibition of neurotransmitter release is the overall pathologic mechanism induced by excessive $\alpha$-syn [33-35]. Then how does mutant $\alpha$-syn cause PD? A dose-dependent toxicity of $\alpha$-syn seen in duplication/triplication cases with an additional effect of homozygosity [36] plus the presence of the protein in LBs support the idea that the pathological mechanism of mutant $\alpha$-syn is through a gain of function. In support of this notion, it has been widely demonstrated that $\alpha$-syn is prone to aggregate into amyloid-like, beta-sheet fibrils [22] and fibrillisation is augmented in the presence of mutations or elevated protein levels [37-39].

Increasing evidence also suggests that phosphorylation may play an important role in modulating $\alpha$-syn aggregation, LB formation, and toxicity [40]. It has been shown that $\alpha$-syn deposited in LBs is highly phosphorylated at serine 129 [41,42] and serine 87 [43]. However, it is still unclear whether phosphorylation enhances or protects against $\alpha$-syn toxicity in vivo. The role of phosphorylation in promoting or inhibiting fibril formation remains controversial. Phosphorylation at serine 129 has been reported to promote fibril formation more readily than unmodified protein, in vitro [41], but inhibition of oligomerization and fibril formation has been also described for serine 87 or serine 129 phosphorylated $\alpha$ syn. An additional study utilizing an in vivo model suggests a lack of correlation between phosphorylation at Ser-129 and the level of $\alpha$-syn fibrillation [44]. Clearly, more research is needed for a coherent view of how phosphorylation alters the physiochemical properties of $\alpha$-syn to emerge.

One interesting property of $\alpha$-syn is its ability to propagate from cell to cell. It has been shown that a proportion of $\alpha$-syn and its aggregates are secreted from neuronal cells via exocytosis [45]. In addition, two studies showed host-to-graft propagation of $\alpha$-syn-positive LB pathology in long-term embryonic nigral transplants in PD [46,47]. In vitro, cultured cells and neurons are capable of taking up $\alpha$-syn aggregates via endocytosis [48] and this observation led to the development of cellular models of $\alpha$-syn aggregation $[49,50]$. It is thought that exogenous fibrillar $\alpha$-syn seeds the formation of LB-like inclusions by incorporating soluble monomeric proteins, in a process possibly analogous to the infectious propagation of prions [49]. Taken together, all these observations strongly support the notion that the presence of fibrils of $\alpha$-syn represents a noxious event that leads to the pathological consequences observed in PD.

\section{LRRK2: a signaling protein that is toxic when mutated}

In 2002 Funayama and collaborators reported a new genetic linkage to dominant inherited PD [51]. Two years later, independent groups not only described additional families with linkage at the same chromosomal locus but also found that the gene responsible for this familial form of PD was Leucine-rich repeat kinase 2 $[8,9]$. In particular one mutation, the glycine to serine substitution at position 2019, was soon recognized to be a very common cause of PD being present in 1 to $40 \%$ (depending on the population) of all PD cases, familial and sporadic. Pathological information of LRRK2 cases is available and suggests a quite variable pathology ranging from typical sporadic pathology with LBs, to ubiquitin, tau and/or TDP-43-positive inclusions, to pure nigral degeneration (reviewed in [52]). Although the majority of cases present with pathological and clinical features undistinguishable from idiopathic PD, a recognized variability in different LRRK2 mutation carriers may suggest that LRRK2 acts upstream of $\alpha$-syn and other proteins implicated in the neurodegeneration associated with protein deposition. Therefore, understanding LRRK2 function might illuminate the pathological pathways that lead to $\alpha$-syn deposition and on mechanisms at work in other LB disorders.

While the pathogenic impact of mutant $\alpha$-syn is, at least in part, understood, the mechanism by which mutant LRRK2 causes PD is less clear. LRRK2 is a large, multidomain GTPase/kinase protein (figure 1B) that undergoes autophosphorylation in vitro [53-56]. Interestingly, pathological mutations cluster within the two enzymatic domains [57], suggesting the possibility that altered signaling is implicated in the disease. Kinase activity is required for mutant proteins to be toxic, at least in neuronal cell models $[55,58]$, further supporting the notion that alteration of LRRK2 signaling might have pathological implications. Clues should come from the effects of pathological mutations on protein activity. 
Only one mutation, the G2019S located in the activation loop of the kinase domain, clearly increases kinase activity (reviewed in [57]), while other mutations do not convincingly do so [57]. Since blocking kinase function rescues the toxicity observed in primary neurons, it is not clear why toxicity is prevented for mutants with unaltered kinase activity. One possible interpretation is that the kinase domain regulates the GTPase/ROC (Ras Of Complex proteins) domain and ROC is the signal output of LRRK2 involved in the pathogenic process. In support of this hypothesis, we and others have shown that the kinase phosphorylates its own ROC domain [59-61], opening the possibility of an intramolecular mechanism of regulation. As mutations in the ROC/ GTPase domain decrease the ability of LRRK2 to hydrolyze GTP [62,63], it can be speculated that the G2019S mutation indirectly affects the catalytic properties of ROC through increased phosphorylation. However, the only experimental measurement of the GTPase activity for the G2019S mutant suggests that there is no significant change compared to the wild-type [64], indicating that different mutations might act in different ways and ultimately converge to a common pathological phenotype. This is also supported by the different pathologies observed among different mutants. Interestingly, pathological mutations associated with PD have not been described in the paralogous protein LRRK1 [65] and analogous LRRK2 mutations are innocuous when artificially introduced in LRRK1 [65].

What is LRRK2's physiological function? LRRK2 has been suggested to play a role in the control and maintenance of neurite length [66-69], in vesicle endocytosis through interaction with Rab5a [70] and vesicle sorting between axons and dendrites [71], in activation of apoptosis through interaction with death adaptor Fas-associated protein with death domain (FADD) [72], and in controlling protein translation through phosphorylation of 4E-BP1 [73] and interaction with the microRNA pathway to regulate protein synthesis [74]. Several groups also reported that LRRK2 interacts with alpha and beta tubulins, the microtubule's building blocks [75-77], suggesting that LRRK2 may play a role in cytoskeleton dynamics. Interestingly, LRRK2 localization with microtubules is enhanced in the presence of the potent LRRK2 inhibitor H-1152 [78], indicating that this interaction is dependent on kinase activity.

What do we know about the mechanism of LRRK2 mediated neurodegeneration? The observation that homozygous cases with G2019S mutation have a clinical presentation undistinguishable from the heterozygotes [79] suggests that the mechanism of LRRK2 pathogenicity may not be a consequence of increased protein activity. This is in apparent contrast with the observation that mutations cause differential effects on protein activity, as discussed above. It is possible that the amount of altered activity is no longer important above a certain threshold (i.e. downstream targets are limiting factors) and therefore having $50 \%$ or $100 \%$ of mutant molecules does not make any difference in terms of cellular effect. This important but still unresolved issue will become more clear when robust physiological substrates of LRRK2 are identified. Although a few LRRK2 substrates have been described [73,77,80-83], we are still awaiting reproducible and physiologically relevant substrates.

Could mutant LRRK2 act with a dominant negative mechanism? A requirement for a mutant protein to operate as dominant negative is that the protein exerts its biological function within a homo or hetero-complex. Several independent groups have now demonstrated that LRRK2 is predominantly a dimer under native conditions [56,84-87]. Interestingly, a recent paper by Tong and collaborators [88] shows that loss of LRRK2 causes accumulation of $\alpha$-syn, increased autophagy and cell death in kidneys of aged mice. These data may indicate that mutations cause loss of function through a dominant negative mechanism. However, why the effect was seen specifically in the kidneys and not in the brain, which is the relevant tissue for the neurodegenerative process, needs to be further elucidated. One explanation suggested by the authors is that the renal tissue has almost undetectable levels of LRRK1 mRNA expression and therefore LRRK1 may not compensate loss of LRRK2 function. What happens when both LRRK1 and LRRK2 are lost? Double-knockout mice for LRRKs have not been reported in the literature and one possibility is that these mice are not viable. In another study, Sheng et al. [89] observed that LRRK2 knock-out in zebrafish by morpholinos is embryonically lethal while deletion of the C-terminal WD40 domain induces a parkinsonismlike loss of neurons and locomotive defects, indicating that LRRK2 function is essential for neuronal survival. This observation supports the notion that LRRK2 mutations cause a loss of protein function.

Interestingly, a few studies reported a number of PD cases with LRRK2 positive staining in LBs of post-mortem sections using different antibodies against LRRK2 [55,90-94]. However, some inconsistency between different studies $[95,96]$ makes the data difficult to interpret, although the lack of reliable immunological tools to detect LRRK2 within cells or tissues is currently a major limitation in the field. Furthermore, different groups reported a mutant-specific tendency of LRRK2 to accumulate into inclusion bodies when overexpressed in cell lines and primary neuronal cultures $[55,66,96,97]$. Sequestration of mutant proteins into inclusion bodies could lead to a loss or a gain of function depending if these aggregates are toxic for the cells. Although the 
main criticism to this observation is that protein overexpression could be a misleading approach as non-physiological levels of a given protein my cause artefactual aggregation, the clear-cut phenotype observed between wild-type and mutant LRRK2 highlights the importance of further investigating LRRK2 aggregation properties and products. Waxman and collaborators observed that LRRK2 inclusions do not recruit $\alpha$-syn when both proteins are co-overexpressed in cell systems [96], hinting that LRRK 2 and $\alpha$-syn deposition might be two independent processes.

Although LRRK2 pathological function is still unclear, a unifying theme of altered dopaminergic neurotransmission is emerging, based on two transgenic mouse models carrying different pathological LRRK2 mutations, suggesting that LRRK2 normal function is crucial at the synaptic level, as proposed by Lee et al., [98].

\section{LRRK2 and $\alpha$-syn: intersecting pathways?}

As discussed above, understanding LRRK 2 and $\alpha$-syn pathways may shed light on the mechanisms that underlie sporadic PD. Is there any evidence that suggests a functional link between $\alpha$-syn and LRRK2? $\alpha$-Syn deposited in LBs is highly phosphorylated at serine 129 [41] and phosphorylated proteins seem to be more prone to aggregation in vitro [41], suggesting that abnormally high levels of phosphorylated proteins may trigger the neurodegenerative process. A simple scenario is that LRRK2 is the kinase that mediates phosphorylation of $\alpha$-syn. However, only one report showed that recombinant $\alpha$-syn is directly phosphorylated by cell lysates overexpressing LRRK2 from HEK293 cells [99], while there is no evidence that LRRK2 causes increased $\alpha$-syn phosphorylation in cell or animal systems. It would be of particular interest to investigate whether pathological brain tissue from LRRK2 cases display increased levels of phosphorylated $\alpha$-syn. One study reported that LRRK2 induces $\alpha$-syn expression via the extracellular signal-regulated kinase pathway, although the effect is modest [100]. Qing and collaborators [101] successfully co-immunoprecipitated LRRK2 and $\alpha$-syn from pathological tissue of diffuse LB cases or from HEK293 cells when exposed to oxidative stress. These data are quite interesting as they hint the possibility that the two proteins localize upon stress to the same cellular compartment where they participate in a common biological process and LRRK2 kinase activity might, directly or indirectly, influence $\alpha$-syn phosphorylation state.

Another possibility is that LRRK2 accelerates the toxicity of $\alpha$-syn via a different mechanism other than phosphorylation. For instance, the role of the GTPase activity of LRRK2 is still a relatively unexplored field and, to date, no LRRK2 partners specific for the GTPbound state of the protein have been reported.
Important clues on the $\alpha$-syn/LRRK2 interplay come from a recent work by Cai and collaborators [102]. Using the tetracycline-controlled transactivator system, they generated a number of inducible transgenic mice overexpressing the human A53T mutant form of $\alpha$-syn, which they crossed with mice transgenic for human LRRK2, including wild-type, G2019S, or kinase domaindeletion mutant in the adult forebrain. They found that co-expression of LRRK2 with A53T $\alpha$-syn dramatically accelerates the neurodegenerative process in a dose dependent manner and independently from the LRRK2 genotype, suggesting the kinase activity is not important for the observed phenotypes. LRRK2 expression led to impairment of microtubule dynamic, Golgi and mitochondria defects. Strikingly, they observed an agedependent accumulation of $\alpha$-syn in double transgenic mice, suggesting that LRRK 2 acts upstream of $\alpha$-syn depositions. Interestingly, loss of LRRK2 (by transgenic knockout) alleviates these phenotypes. Although these data are quite illuminating in establishing a functional link between LRRK 2 and $\alpha$-syn, whether this also happens in the DA neurons of the midbrain, is an important question that needs to be addressed.

Are LRRK2 and $\alpha$-syn physically found in the same compartments? We have already discussed that $\alpha$-syn interacts with membranes where it acquires an alphahelical conformation. LRRK2 is also found in association with membranous structures $[82,87,103,104]$. It is associated with small vesicles and it interacts with Rab5 playing a possible role in vesicle endocytosis at the synaptic terminal [70]. This is an interesting aspect as it links LRRK2 and $\alpha$-syn, which is also thought to play a role in synaptic vesicle recycling, as discussed above. Both LRRK2 and $\alpha$-syn have also been proposed to interact with lipid rafts $[16,105]$. Lipid rafts are organized membrane microdomains that serve as platforms for intracellular signaling. These domains are organized by specialized scaffold proteins and one hypothesis is that LRRK2 could function as a scaffolding molecule mediating heterologous interactions through its predicted protein-protein interaction domains (i.e. Leucinerich repeats and WD40 domain). Mutations could impair LRRK2 ability to properly organize the lipid raft with direct consequence on $\alpha$-syn interactions with these domains.

In another study, Sakaguchi-Nakashima et al. [71] investigated the function of LRK-1, the C. elegans homolog of LRRK1/2. They proposed that LRK-1 controls a polarized sorting of synaptic vesicle proteins to the axons, excluding them from the dendrite-specific transport. It can be speculated that an altered axonaltransport due to the presence of pathological LRRK2 mutations, could lead to an over-accumulation of toxic proteins, like $\alpha$-syn, in dopaminergic neurons. 
Another set of observations linking LRRK2 and $\alpha$-syn converge to microtubule dynamics and axonal transport. In the process of organelle transport along the axons, for example synaptic vesicles, binding of kinesin to microtubules requires the presence of JIPs (JNK interacting proteins) - a family of scaffolding molecules that adapt the binding of cargoes to kinesin [106]. Interestingly, JIPs have been proposed to interact with LRRK2 [107]. Furthermore, as JIPs bind to the protein kinase MKK7, also LRRK2 is capable to interact with MKK7 [82]. By binding to tubulins, LRRK2 stabilizes microtubules in vitro [77]. A possible readout is that LRRK2 is upstream of $\alpha$-syn and acts as a scaffolding signaling molecule required for organelle transport and microtubule assembly and stability. On the other hand, several experimental evidences indicate that LRRK2 causes tau hyperphosphorylation, an event that is believed to induce destabilization of microtubules [66,108-110]. Altered LRRK2 function by mutations may lead to increased microtubule destabilization and, as a result, improper transport of vesicle bound- $\alpha$-syn with consequent protein accumulation and, in turn, cell death (Figure 2).

What is LRRK2 role in signal transduction? There is mounting evidence that LRRK2 might be involved in a mitogen-activated protein kinase (MAPK)-related pathway. Overexpression of LRRK2 increases ERK1/2 phosphorylation [100,111] and LRRK2 interacts with and phosphorylates in vitro the MAPKKs MKK3, 6 and 7 $[81,82]$. Also, LRRK2 is involved in the regulation of neurite outgrowth and mutant LRRK2 causes neurite shrinkage $[66,67]$. Since MAPK pathway may play a role in neurite outgrowth [112], it is possible that LRRK2

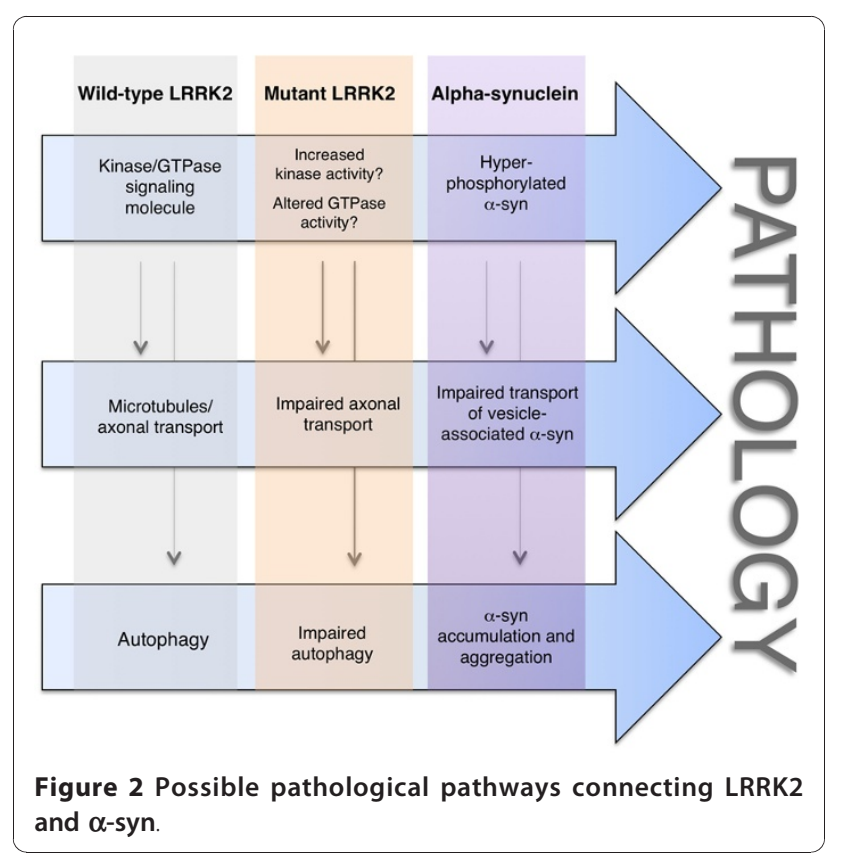

modulates neurite morphology and length through MEK/ERK phosphorylation. Interestingly, a recent study uncovered that LRRK1, the close LRRK2 homologue, is part of a complex including Grb2/Gab2/Shc1 (adaptor proteins for Ras activation) and that this signal integrator complex is involved in the balance of cellular stress responses (influencing both ERK and JNK) only if LRRK1 is functional [113]. Based on these observations, one could speculate that unbalanced phosphorylation of downstream components of a MAPK-related pathway, as a consequence LRRK2 mutations, could in turn affect the phosphorylation state of $\alpha$-syn.

An interesting work by Sancho and collaborators [114] places LRRK2 in the Wnt (Wingless/Int) signaling pathway by a direct interaction with Dishevelled (DVL) proteins through the ROC-COR domain. Interestingly, LRRK2 enhances tau phosphorylation through the downstream target of DVLs GSK-3beta [110] while (i) tau phosphorylation by GSK3-beta is $\alpha$-syn-dependent [115] and (ii) the phosphorylation of the $\alpha$-syn interacting protein synphilin-1 is mediated by GSK3-beta [116]. Furthermore, Li and co-workers observed increased phosphorylation of Tau in a mouse model of mutant LRRK2 [108]. Taken together, these observations further expand an emerging link between PD and tau, as variations in the MAPT gene are associated with increased risk of PD [3] and LRRK2 and tau, which, as discussed earlier, is deposited in a number of LRRK2 cases.

Another set of interesting data links the chaperone proteins 14-3-3 with both LRRK2 and $\alpha$-syn. 14-3-3 proteins, a highly conserved chaperone family consisting of seven known mammalian isoforms, regulate a variety of cellular processes including intracellular trafficking and protein interaction [117]. They have been shown to form a complex with $\alpha$-syn [118] and to co-localize with LBs in PD and diffuse LB disease [119]. Furthermore, 14-3-3 proteins protect against neurotoxicity and aggregation of $\alpha$-syn in a number of cellular and animal models [120]. Two recent papers have reported that 143-3 also interacts with LRRK2 by binding two phosphorylated serine residues (S910 and S935) [78,97]. Interestingly, site-specific mutagenesis of the two serine residues or pharmacological inhibition of LRRK2 with H-1152, not only abolished the binding of LRRK2 with 14-3-3, but also caused the proteins to accumulate into aggresome-like structure in HEK293T cells. This aggregation phenotype was also observed in a number of pathological LRRK2 mutants (unable to bind to 14-3-3), strongly suggesting that 14-3-3 binding prevents LRRK2 aggregation. Collectively, these observations suggest that mutations in $\alpha$-syn and LRRK2 or high dose of $\alpha$-syn may disrupt or alter the ability of 14-3-3 to keep both proteins properly soluble with consequent increase in protein aggregation and, in turn, neurotoxicity. 
Another potential mechanism by which mutant LRRK2 could promote $\alpha$-syn aggregation is through impairment of autophagy. There are few studies highlighting a role of LRRK2 in the autophagic pathway. LRRK2 null mice display impaired autophagy function, accumulation of $\alpha$-syn in the kidneys and consequent cell death [88], suggesting that LRRK2 function is implicated in the autophagic pathway and, if mutations cause loss of function, they may impair autophagy. In HEK293 cells, expression of R1441C mutant causes impairment of autophagy by accumulation of autophagic vacuoles containing incompletely degraded material and increased levels of p62 [121]. Furthermore, overexpression of G2019S mutant in the neuroblastoma line SHSY5Y not only resulted in increased autophagic vacuoles but also caused neurite shrinkage [68], perhaps suggesting that the two events are related. Interestingly, wildtype $\alpha$-syn is selectively translocated into lysosomes for degradation by the chaperone-mediated autophagy (CMA) pathway in isolated liver lysosomes. The pathogenic A53T and A30P mutants bound to the receptor for this pathway on the lysosomal membrane, but appeared to act as uptake blockers, inhibiting both their own degradation and that of other substrates [122]. Moreover, CMA inhibition leads to an accumulation of soluble high molecular weight and detergent-insoluble species of $\alpha$-syn, suggesting that CMA dysfunction may play a role in the generation of such aberrant species in PD [123]. Autophagy impairment caused by mutant LRRK2 may result in accumulation of misfolded $\alpha$-syn similarly to the effect of $\alpha$-syn mutations (Figure 2).

\section{Conclusions}

The future key steps in the field will be the acquisition of a clearer picture of LRRK2 signaling, including specific substrates, the GTPase activating proteins (GAPs) and the guanine-exchange factors (GEFs), and the kinases and phosphatases that finely tune its function. This will also allow to better understand how LRRK2 signaling influences $\alpha$-syn function, with important therapeutic implications being LRRK2 a protein kinase and therefore an excellent pharmacological target.

\footnotetext{
Acknowledgements

We would like to thank Dr. Patrick A. Lewis for critically reading the manuscript.

This work was supported by grants from the University of Padova, from the CariTrento e Rovereto, the MIUR (PRIN2008) and the Michael J Fox

foundation. EG is supported by the MIUR (Rientro dei Cervelli) and LC by the Michael J Fox foundation.
}

\section{Authors' contributions}

$E G, M B, L C$ and $L B$ conceived and wrote the manuscript. All authors read and approved the final draft.

\section{Competing interests}

The authors declare that they have no competing interests.

Received: 3 November 2010 Accepted: 18 January 2011

Published: 18 January 2011

\section{References}

1. Spillantini MG, Schmidt ML, Lee VM, Trojanowski JQ, Jakes R, Goedert M: Alpha-synuclein in Lewy bodies. Nature 1997, 388(6645):839-840.

2. Polymeropoulos MH, Lavedan C, Leroy E, Ide SE, Dehejia A, Dutra A, Pike B, Root $\mathrm{H}$, Rubenstein J, Boyer $\mathrm{R}$, et al: Mutation in the alpha-synuclein gene identified in families with Parkinson's disease. Science 1997, 276(5321):2045-2047.

3. Simon-Sanchez J, Schulte C, Bras JM, Sharma M, Gibbs JR, Berg D, PaisanRuiz C, Lichtner P, Scholz SW, Hernandez DG, et al: Genome-wide association study reveals genetic risk underlying Parkinson's disease. Nat Genet 2009, 41(12):1308-1312

4. Satake W, Nakabayashi Y, Mizuta I, Hirota Y, Ito C, Kubo M, Kawaguchi T, Tsunoda T, Watanabe M, Takeda A, et al: Genome-wide association study identifies common variants at four loci as genetic risk factors for Parkinson's disease. Nat Genet 2009, 41(12):1303-1307.

5. Kitada T, Asakawa S, Hattori N, Matsumine H, Yamamura Y, Minoshima S, Yokochi M, Mizuno $Y$, Shimizu N: Mutations in the parkin gene cause autosomal recessive juvenile parkinsonism. Nature 1998, 392(6676):605-608

6. Bonifati V, Rizzu P, van Baren MJ, Schaap O, Breedveld GJ, Krieger E, Dekker MC, Squitieri F, Ibanez P, Joosse M, et al: Mutations in the DJ-1 gene associated with autosomal recessive early-onset parkinsonism. Science 2003, 299(5604):256-259.

7. Valente EM, Salvi S, lalongo T, Marongiu R, Elia AE, Caputo V, Romito L, Albanese A, Dallapiccola B, Bentivoglio AR: PINK1 mutations are associated with sporadic early-onset parkinsonism. Ann Neurol 2004, 56(3):336-341.

8. Zimprich A, Biskup S, Leitner P, Lichtner P, Farrer M, Lincoln S, Kachergus J, Hulihan M, Uitti RJ, Calne DB, et al: Mutations in LRRK2 cause autosomaldominant parkinsonism with pleomorphic pathology. Neuron 2004, 44(4):601-607.

9. Paisan-Ruiz C, Jain S, Evans EW, Gilks WP, Simon J, van der Brug M, Lopez A, Aparicio S, Gil AM, Khan N, et al: Cloning of the gene containing mutations that cause PARK8-linked Parkinson's disease. Neuron 2004, 44(4):595-600

10. Paisan-Ruiz C, Nath P, Washecka N, Gibbs JR, Singleton AB: Comprehensive analysis of LRRK2 in publicly available Parkinson's disease cases and neurologically normal controls. Hum Mutat 2008, 29(4):485-490.

11. Kruger R, Kuhn W, Muller T, Woitalla D, Graeber M, Kosel S, Przuntek H, Epplen JT, Schols L, Riess O: Ala30Pro mutation in the gene encoding alpha-synuclein in Parkinson's disease. Nat Genet 1998, 18(2):106-108.

12. Zarranz JJ, Alegre J, Gomez-Esteban JC, Lezcano E, Ros R, Ampuero I, Vidal L, Hoenicka J, Rodriguez O, Atares B, et al: The new mutation, E46K, of alpha-synuclein causes Parkinson and Lewy body dementia. Ann Neurol 2004, 55(2):164-173.

13. Chartier-Harlin MC, Kachergus J, Roumier C, Mouroux V, Douay X, Lincoln S, Levecque C, Larvor L, Andrieux J, Hulihan M, et al: Alpha-synuclein locus duplication as a cause of familial Parkinson's disease. Lancet 2004, 364(9440):1167-1169.

14. Iwai A, Masliah E, Yoshimoto M, Ge N, Flanagan L, de Silva HA, Kittel A, Saitoh T: The precursor protein of non-A beta component of Alzheimer's disease amyloid is a presynaptic protein of the central nervous system. Neuron 1995, 14(2):467-475

15. Lee $\mathrm{SJ}$, Jeon $\mathrm{H}$, Kandror KV: Alpha-synuclein is localized in a subpopulation of rat brain synaptic vesicles. Acta Neurobiol Exp (Wars) 2008, 68(4):509-515.

16. Fortin DL, Troyer MD, Nakamura K, Kubo S, Anthony MD, Edwards RH: Lipid rafts mediate the synaptic localization of alpha-synuclein. J Neurosci 2004, 24(30):6715-6723.

17. Davidson WS, Jonas A, Clayton DF, George JM: Stabilization of alphasynuclein secondary structure upon binding to synthetic membranes. J Biol Chem 1998, 273(16):9443-9449.

18. Giasson Bl, Murray IV, Trojanowski JQ, Lee VM: A hydrophobic stretch of 12 amino acid residues in the middle of alpha-synuclein is essential for filament assembly. J Biol Chem 2001, 276(4):2380-2386. 
19. Murray IV, Giasson Bl, Quinn SM, Koppaka V, Axelsen PH, Ischiropoulos H, Trojanowski JQ, Lee VM: Role of alpha-synuclein carboxy-terminus on fibril formation in vitro. Biochemistry 2003, 42(28):8530-8540.

20. Cole NB, Murphy DD, Grider T, Rueter S, Brasaemle D, Nussbaum RL: Lipid droplet binding and oligomerization properties of the Parkinson's disease protein alpha-synuclein. J Biol Chem 2002, 277(8):6344-6352.

21. McLean PJ, Kawamata H, Ribich S, Hyman BT: Membrane association and protein conformation of alpha-synuclein in intact neurons. Effect of Parkinson's disease-linked mutations. J Biol Chem 2000, 275(12):8812-8816.

22. Bisaglia M, Mammi S, Bubacco L: Structural insights on physiological functions and pathological effects of alpha-synuclein. Faseb J 2009, 23(2):329-340.

23. Willingham S, Outeiro TF, DeVit MJ, Lindquist SL, Muchowski PJ: Yeast genes that enhance the toxicity of a mutant huntingtin fragment or alpha-synuclein. Science 2003, 302(5651):1769-1772.

24. Darios F, Ruiperez V, Lopez I, Villanueva J, Gutierrez LM, Davletov B: Alphasynuclein sequesters arachidonic acid to modulate SNARE-mediated exocytosis. EMBO Rep 2010, 11(7):528-533.

25. Burre J, Sharma M, Tsetsenis T, Buchman V, Etherton MR, Sudhof TC: Alphasynuclein promotes SNARE-complex assembly in vivo and in vitro. Science 2010, 329(5999):1663-1667.

26. Perez RG, Waymire JC, Lin E, Liu JJ, Guo F, Zigmond MJ: A role for alphasynuclein in the regulation of dopamine biosynthesis. J Neurosci 2002. 22(8):3090-3099.

27. Tehranian R, Montoya SE, Van Laar AD, Hastings TG, Perez RG: Alphasynuclein inhibits aromatic amino acid decarboxylase activity in dopaminergic cells. J Neurochem 2006, 99(4):1188-1196.

28. Fountaine TM, Wade-Martins R: RNA interference-mediated knockdown of alpha-synuclein protects human dopaminergic neuroblastoma cells from MPP(+) toxicity and reduces dopamine transport. J Neurosci Res 2007, 85(2):351-363.

29. Chandra S, Fornai F, Kwon HB, Yazdani U, Atasoy D, Liu X, Hammer RE, Battaglia G, German DC, Castillo PE, et al: Double-knockout mice for alphaand beta-synucleins: effect on synaptic functions. Proc Natl Acad Sci USA 2004, 101(41):14966-14971

30. Abeliovich A, Schmitz Y, Farinas I, Choi-Lundberg D, Ho WH, Castillo PE, Shinsky N, Verdugo JM, Armanini M, Ryan A, et al: Mice lacking alphasynuclein display functional deficits in the nigrostriatal dopamine system. Neuron 2000, 25(1):239-252.

31. Cabin DE, Shimazu K, Murphy D, Cole NB, Gottschalk W, Mcllwain KL, Orrison B, Chen A, Ellis CE, Paylor R, et al: Synaptic vesicle depletion correlates with attenuated synaptic responses to prolonged repetitive stimulation in mice lacking alpha-synuclein. J Neurosci 2002, 22(20):8797-8807.

32. Greten-Harrison B, Polydoro M, Morimoto-Tomita M, Diao L, Williams AM, Nie EH, Makani S, Tian N, Castillo PE, Buchman VL, et al: \{alpha\}\{beta\} \{gamma\}-Synuclein triple knockout mice reveal age-dependent neuronal dysfunction. Proc Natl Acad Sci USA 2010, 107(45):19573-8.

33. Larsen $K E$, Schmitz $Y$, Troyer MD, Mosharov E, Dietrich P, Quazi AZ, Savalle M, Nemani V, Chaudhry FA, Edwards RH, et al: Alpha-synuclein overexpression in $\mathrm{PC} 12$ and chromaffin cells impairs catecholamine release by interfering with a late step in exocytosis. J Neurosci 2006, 26(46):11915-11922.

34. Nemani VM, Lu W, Berge V, Nakamura K, Onoa B, Lee MK, Chaudhry FA, Nicoll RA, Edwards RH: Increased expression of alpha-synuclein reduces neurotransmitter release by inhibiting synaptic vesicle reclustering after endocytosis. Neuron 2010, 65(1):66-79.

35. Scott DA, Tabarean I, Tang Y, Cartier A, Masliah E, Roy S: A pathologic cascade leading to synaptic dysfunction in alpha-synuclein-induced neurodegeneration. J Neurosci 2010, 30(24):8083-8095.

36. Ikeuchi T, Kakita A, Shiga A, Kasuga K, Kaneko H, Tan CF, Idezuka J, Wakabayashi K, Onodera O, Iwatsubo T, et al: Patients homozygous and heterozygous for SNCA duplication in a family with parkinsonism and dementia. Arch Neurol 2008, 65(4):514-519.

37. Conway KA, Harper JD, Lansbury PT: Accelerated in vitro fibril formation by a mutant alpha-synuclein linked to early-onset Parkinson disease. Nat Med 1998, 4(11):1318-1320.

38. Li J, Uversky VN, Fink AL: Effect of familial Parkinson's disease point mutations $\mathrm{A} 30 \mathrm{P}$ and $\mathrm{A} 53 \mathrm{~T}$ on the structural properties, aggregation, and fibrillation of human alpha-synuclein. Biochemistry 2001, 40(38):11604-11613.
39. Shtilerman MD, Ding TT, Lansbury PT Jr: Molecular crowding accelerates fibrillization of alpha-synuclein: could an increase in the cytoplasmic protein concentration induce Parkinson's disease? Biochemistry 2002, 41(12):3855-3860.

40. Nonaka T, Watanabe ST, Iwatsubo T, Hasegawa M: Seeded Aggregation and Toxicity of \{alpha\}-Synuclein and Tau: CELLULAR MODELS OF NEURODEGENERATIVE DISEASES. J Biol Chem 2010, 285(45):34885-34898.

41. Fujiwara H, Hasegawa M, Dohmae N, Kawashima A, Masliah E, Goldberg MS, Shen J, Takio K, Iwatsubo T: alpha-Synuclein is phosphorylated in synucleinopathy lesions. Nat Cell Biol 2002, 4(2):160-164.

42. Anderson JP, Walker DE, Goldstein JM, de Laat R, Banducci K, Caccavello RJ, Barbour R, Huang J, Kling K, Lee M, et al: Phosphorylation of Ser-129 is the dominant pathological modification of alpha-synuclein in familial and sporadic Lewy body disease. J Biol Chem 2006, 281(40):29739-29752.

43. Paleologou KE, Oueslati A, Shakked G, Rospigliosi CC, Kim HY, Lamberto GR, Fernandez CO, Schmid A, Chegini F, Gai WP, et al: Phosphorylation at $\mathbf{8 8 7}$ is enhanced in synucleinopathies, inhibits alpha-synuclein oligomerization, and influences synuclein-membrane interactions. J Neurosci 2010, 30(9):3184-3198.

44. Chen L, Feany MB: Alpha-synuclein phosphorylation controls neurotoxicity and inclusion formation in a Drosophila model of Parkinson disease. Nat Neurosci 2005, 8(5):657-663.

45. Lee HJ, Patel S, Lee SJ: Intravesicular localization and exocytosis of alphasynuclein and its aggregates. J Neurosci 2005, 25(25):6016-6024.

46. Kordower JH, Chu Y, Hauser RA, Freeman TB, Olanow CW: Lewy body-like pathology in long-term embryonic nigral transplants in Parkinson's disease. Nat Med 2008, 14(5):504-506.

47. Li JY, Englund E, Holton JL, Soulet D, Hagell P, Lees AJ, Lashley T, Quinn NP, Rehncrona S, Bjorklund A, et al: Lewy bodies in grafted neurons in subjects with Parkinson's disease suggest host-to-graft disease propagation. Nat Med 2008, 14(5):501-503.

48. Lee HJ, Suk JE, Bae EJ, Lee SJ: Clearance and deposition of extracellular alpha-synuclein aggregates in microglia. Biochem Biophys Res Commun 2008, 372(3):423-428

49. Luk KC, Song C, O'Brien P, Stieber A, Branch JR, Brunden KR, Trojanowski JQ Lee VM: Exogenous alpha-synuclein fibrils seed the formation of Lewy body-like intracellular inclusions in cultured cells. Proc Natl Acad Sci USA 2009, 106(47):20051-20056.

50. Waxman EA, Giasson BI: A novel, high-efficiency cellular model of fibrillar alpha-synuclein inclusions and the examination of mutations that inhibit amyloid formation. J Neurochem 2010, 113(2):374-388.

51. Funayama M, Hasegawa K, Kowa H, Saito M, Tsuji S, Obata F: A new locus for Parkinson's disease (PARK8) maps to chromosome 12p11.2-q13.1. Ann Neurol 2002, 51(3):296-301.

52. Wider C, Dickson DW, Wszolek ZK: Leucine-rich repeat kinase 2 geneassociated disease: redefining genotype-phenotype correlation. Neurodegener Dis 2010, 7(1-3):175-179.

53. West $A B$, Moore DJ, Biskup S, Bugayenko A, Smith WW, Ross CA, Dawson VL, Dawson TM: Parkinson's disease-associated mutations in leucine-rich repeat kinase 2 augment kinase activity. Proc Natl Acad Sci USA 2005, 102(46):16842-16847.

54. Gloeckner CJ, Kinkl N, Schumacher A, Braun RJ, O'Neill E, Meitinger T, Kolch W, Prokisch $H$, Ueffing M: The Parkinson disease causing LRRK2 mutation I2020T is associated with increased kinase activity. Hum Mol Genet 2006, 15(2):223-232.

55. Greggio E, Jain S, Kingsbury A, Bandopadhyay R, Lewis P, Kaganovich A, van der Brug MP, Beilina A, Blackinton J, Thomas KJ, et al: Kinase activity is required for the toxic effects of mutant LRRK2/dardarin. Neurobiol Dis 2006, 23(2):329-341.

56. Greggio E, Zambrano I, Kaganovich A, Beilina A, Taymans JM, Daniels V, Lewis P, Jain S, Ding J, Syed A, et al: The Parkinson disease-associated leucine-rich repeat kinase 2 (LRRK2) is a dimer that undergoes intramolecular autophosphorylation. J Biol Chem 2008, 283(24):16906-16914.

57. Greggio E, Cookson MR: Leucine-rich repeat kinase 2 mutations and Parkinson's disease: three questions. ASN Neuro 2009, 1(1).

58. Smith WW, Pei Z, Jiang H, Dawson VL, Dawson TM, Ross CA: Kinase activity of mutant LRRK2 mediates neuronal toxicity. Nat Neurosci 2006, 9(10):1231-1233

59. Greggio E, Taymans JM, Zhen EY, Ryder J, Vancraenenbroeck R, Beilina A, Sun P, Deng J, Jaffe H, Baekelandt V, et al: The Parkinson's disease kinase 
LRRK2 autophosphorylates its GTPase domain at multiple sites. Biochem Biophys Res Commun 2009, 389(3):449-454

60. Kamikawaji $\mathrm{S}$, Ito $\mathrm{G}$, Iwatsubo T: Identification of the autophosphorylation sites of LRRK2. Biochemistry 2009, 48(46):10963-10975.

61. Gloeckner CJ, Boldt K, von Zweydorf F, Helm S, Wiesent L, Sarioglu H, Ueffing M: Phosphopeptide analysis reveals two discrete clusters of phosphorylation in the $\mathrm{N}$-terminus and the Roc domain of the Parkinson-disease associated protein kinase LRRK2. J Proteome Res 2010, 9(4):1738-1745.

62. Lewis PA, Greggio E, Beilina A, Jain S, Baker A, Cookson MR: The R1441C mutation of LRRK2 disrupts GTP hydrolysis. Biochem Biophys Res Commun 2007, 357(3):668-671

63. Li X, Tan YC, Poulose S, Olanow CW, Huang XY, Yue Z: Leucine-rich repeat kinase 2 (LRRK2)/PARK8 possesses GTPase activity that is altered in familial Parkinson's disease R1441C/G mutants. J Neurochem 2007, 103(1):238-247.

64. Xiong Y, Coombes CE, Kilaru A, Li X, Gitler AD, Bowers WJ, Dawson VL, Dawson TM, Moore DJ: GTPase activity plays a key role in the pathobiology of LRRK2. PLOS Genet 6(4):e1000902.

65. Greggio E, Lewis PA, van der Brug MP, Ahmad R, Kaganovich A, Ding J, Beilina A, Baker AK, Cookson MR: Mutations in LRRK2/dardarin associated with Parkinson disease are more toxic than equivalent mutations in the homologous kinase LRRK1. J Neurochem 2007, 102(1):93-102.

66. MacLeod D, Dowman J, Hammond R, Leete T, Inoue K, Abeliovich A: The familial Parkinsonism gene LRRK2 regulates neurite process morphology. Neuron 2006, 52(4):587-593.

67. Wang L, Xie C, Greggio E, Parisiadou L, Shim H, Sun L, Chandran J, Lin X, Lai C, Yang WJ, et al: The chaperone activity of heat shock protein 90 is critical for maintaining the stability of leucine-rich repeat kinase 2 . J Neurosci 2008, 28(13):3384-3391.

68. Plowey ED, Cherra SJ, Liu YJ, Chu CT: Role of autophagy in G2019SLRRK2-associated neurite shortening in differentiated SH-SY5Y cells. J Neurochem 2008, 105(3):1048-1056.

69. Parisiadou L, Xie C, Cho HJ, Lin X, Gu XL, Long CX, Lobbestael E, Baekelandt V, Taymans JM, Sun L, et al: Phosphorylation of ezrin/radixin/ moesin proteins by LRRK2 promotes the rearrangement of actin cytoskeleton in neuronal morphogenesis. J Neurosci 2009, 29(44):13971-13980.

70. Shin N, Jeong H, Kwon J, Heo HY, Kwon JJ, Yun HJ, Kim CH, Han BS, Tong $Y$, Shen J, et al: LRRK2 regulates synaptic vesicle endocytosis. Exp Cell Res 2008, 314(10):2055-2065.

71. Sakaguchi-Nakashima A, Meir JY, Jin Y, Matsumoto K, Hisamoto N: LRK-1, a C. elegans PARK8-related kinase, regulates axonal-dendritic polarity of SV proteins. Curr Biol 2007, 17(7):592-598.

72. Ho CC, Rideout HJ, Ribe E, Troy CM, Dauer WT: The Parkinson disease protein leucine-rich repeat kinase 2 transduces death signals via Fasassociated protein with death domain and caspase-8 in a cellular model of neurodegeneration. J Neurosci 2009, 29(4):1011-1016.

73. Imai Y, Gehrke S, Wang HQ, Takahashi R, Hasegawa K, Oota E, Lu B: Phosphorylation of $4 \mathrm{E}-\mathrm{BP}$ by LRRK2 affects the maintenance of dopaminergic neurons in Drosophila. Embo J 2008, 27(18):2432-2443.

74. Gehrke S, Imai Y, Sokol N, Lu B: Pathogenic LRRK2 negatively regulates microRNA-mediated translational repression. Nature 2010, 466(7306):637-641

75. Gandhi PN, Wang X, Zhu X, Chen SG, Wilson-Delfosse AL: The Roc domain of leucine-rich repeat kinase 2 is sufficient for interaction with microtubules. J Neurosci Res 2008, 86(8):1711-1720.

76. Gillardon F: Interaction of elongation factor 1-alpha with leucine-rich repeat kinase 2 impairs kinase activity and microtubule bundling in vitro. Neuroscience 2009, 163(2):533-539.

77. Gillardon F: Leucine-rich repeat kinase 2 phosphorylates brain tubulinbeta isoforms and modulates microtubule stability-a point of convergence in parkinsonian neurodegeneration? J Neurochem 2009, 110(5):1514-1522.

78. Dzamko N, Deak M, Hentati F, Reith AD, Prescott AR, Alessi DR, Nichols RJ Inhibition of LRRK2 kinase activity leads to dephosphorylation of Ser (910)/Ser(935), disruption of 14-3-3 binding and altered cytoplasmic localization. Biochem J 2010, 430(3):405-413.

79. Ishihara L, Warren L, Gibson R, Amouri R, Lesage S, Durr A, Tazir M, Wszolek ZK, Uitti RJ, Nichols WC, et al: Clinical features of Parkinson disease patients with homozygous leucine-rich repeat kinase 2 G2019S mutations. Arch Neurol 2006, 63(9):1250-1254.

80. Jaleel M, Nichols RJ, Deak M, Campbell DG, Gillardon F, Knebel A, Alessi DR: LRRK2 phosphorylates moesin at threonine-558: characterization of how Parkinson's disease mutants affect kinase activity. Biochem J 2007, 405(2):307-317.

81. Gloeckner CJ, Schumacher A, Boldt K, Ueffing M: The Parkinson diseaseassociated protein kinase LRRK2 exhibits MAPKKK activity and phosphorylates MKK3/6 and MKK4/7, in vitro. J Neurochem 2009, 109(4):959-968.

82. Hsu CH, Chan D, Greggio E, Saha S, Guillily MD, Ferree A, Raghavan K, Shen GC, Segal L, Ryu H, et al: MKK6 binds and regulates expression of Parkinson's disease-related protein LRRK2. J Neurochem 2010, 112(6):1593-1604.

83. Kanao $T$, Venderova K, Park DS, Unterman T, Lu B, Imai Y: Activation of FoxO by LRRK2 induces expression of proapoptotic proteins and alters survival of postmitotic dopaminergic neuron in Drosophila. Hum Mol Genet 2010, 19(19):3747-3758

84. Sen S, Webber PJ, West AB: Dependence of leucine-rich repeat kinase 2 (LRRK2) kinase activity on dimerization. J Biol Chem 2009, 284(52):36346-36356

85. Jorgensen ND, Peng Y, Ho CC, Rideout HJ, Petrey D, Liu P, Dauer WT: The WD40 domain is required for LRRK2 neurotoxicity. PLoS One 2009, 4(12):e8463.

86. Klein CL, Rovelli G, Springer W, Schall C, Gasser T, Kahle PJ: Homo- and heterodimerization of ROCO kinases: LRRK2 kinase inhibition by the LRRK2 ROCO fragment. J Neurochem 2009, 111(3):703-715.

87. Berger Z, Smith KA, Lavoie MJ: Membrane localization of LRRK2 is associated with increased formation of the highly active LRRK2 dimer and changes in its phosphorylation. Biochemistry 2010, 49(26):5511-5523.

88. Tong Y, Yamaguchi H, Giaime E, Boyle S, Kopan R, Kelleher RJ, Shen J: Loss of leucine-rich repeat kinase 2 causes impairment of protein degradation pathways, accumulation of alpha-synuclein, and apoptotic cell death in aged mice. Proc Natl Acad Sci USA 2010, 107(21):9879-9884.

89. Sheng D, Qu D, Kwok KH, Ng SS, Lim AY, Aw SS, Lee CW, Sung WK, Tan EK, Lufkin T, et al: Deletion of the WD40 domain of LRRK2 in Zebrafish causes Parkinsonism-like loss of neurons and locomotive defect. PLoS Genet 2010, 6(4):e1000914.

90. Giasson Bl, Covy JP, Bonini NM, Hurtig HI, Farrer MJ, Trojanowski JQ, Van Deerlin VM: Biochemical and pathological characterization of Lrrk2. Ann Neurol 2006, 59(2):315-322.

91. Zhu X, Siedlak SL, Smith MA, Perry G, Chen SG: LRRK2 protein is a component of Lewy bodies. Ann Neurol 2006, 60(5):617-618, author reply 618-619.

92. Melrose HL, Kent CB, Taylor JP, Dachsel JC, Hinkle KM, Lincoln SJ, Mok SS, Culvenor JG, Masters CL, Tyndall GM, et al: A comparative analysis of leucine-rich repeat kinase 2 (Lrrk2) expression in mouse brain and Lewy body disease. Neuroscience 2007, 147(4):1047-1058.

93. Perry G, Zhu X, Babar AK, Siedlak SL, Yang Q, Ito G, Iwatsubo T, Smith MA, Chen SG: Leucine-rich repeat kinase 2 colocalizes with alpha-synuclein in Parkinson's disease, but not tau-containing deposits in tauopathies. Neurodegener Dis 2008, 5(3-4):222-224.

94. Alegre-Abarrategui J, Ansorge O, Esiri M, Wade-Martins R: LRRK2 is a component of granular alpha-synuclein pathology in the brainstem of Parkinson's disease. Neuropathol Appl Neurobiol 2008, 34(3):272-283.

95. Higashi S, Biskup S, West AB, Trinkaus D, Dawson VL, Faull RL, Waldvogel HJ, Arai H, Dawson TM, Moore DJ, et al: Localization of Parkinson's disease-associated LRRK2 in normal and pathological human brain. Brain Res 2007, 1155:208-219.

96. Waxman EA, Covy JP, Bukh I, Li X, Dawson TM, Giasson BI: Leucine-rich repeat kinase 2 expression leads to aggresome formation that is not associated with alpha-synuclein inclusions. I Neuropathol Exp Neurol 2009, 68(7):785-796.

97. Nichols RJ, Dzamko N, Morrice NA, Campbell DG, Deak M, Ordureau A, Macartney T, Tong Y, Shen J, Prescott AR, et al: 14-3-3 binding to LRRK2 is disrupted by multiple Parkinson's disease-associated mutations and regulates cytoplasmic localization. Biochem J 2010, 430(3):393-404.

98. Lee S, Liu HP, Lin WY, Guo H, Lu B: LRRK2 Kinase Regulates Synaptic Morphology through Distinct Substrates at the Presynaptic and Postsynaptic Compartments of the Drosophila Neuromuscular Junction. J Neurosci 2010, 30(50):16959-16969. 
99. Qing H, Wong W, McGeer EG, McGeer PL: Lrrk2 phosphorylates alpha synuclein at serine 129: Parkinson disease implications. Biochem Biophys Res Commun 2009, 387(1):149-152.

100. Carballo-Carbajal I, Weber-Endress S, Rovelli G, Chan D, Wolozin B, Klein CL, Patenge N, Gasser T, Kahle PJ: Leucine-rich repeat kinase 2 induces alphasynuclein expression via the extracellular signal-regulated kinase pathway. Cell Signal 2010, 22(5):821-827.

101. Qing H, Zhang Y, Deng Y, McGeer EG, McGeer PL: Lrrk2 interaction with alpha-synuclein in diffuse Lewy body disease. Biochem Biophys Res Commun 2009, 390(4):1229-1234.

102. Lin $X$, Parisiadou L, Gu XL, Wang L, Shim H, Sun L, Xie C, Long CX, Yang WJ, Ding J, et al: Leucine-rich repeat kinase 2 regulates the progression of neuropathology induced by Parkinson's-disease-related mutant alpha-synuclein. Neuron 2009, 64(6):807-827.

103. Biskup S, Moore DJ, Celsi F, Higashi S, West AB, Andrabi SA, Kurkinen K, Yu SW, Savitt JM, Waldvogel HJ, et al: Localization of LRRK2 to membranous and vesicular structures in mammalian brain. Ann Neurol 2006, 60(5):557-569.

104. Vitte J, Traver S, Maues De Paula A, Lesage S, Rovelli G, Corti O, Duyckaerts C, Brice A: Leucine-rich repeat kinase 2 is associated with the endoplasmic reticulum in dopaminergic neurons and accumulates in the core of Lewy bodies in Parkinson disease. J Neuropathol Exp Neurol 2010, 69(9):959-972.

105. Hatano T, Kubo S, Imai S, Maeda M, Ishikawa K, Mizuno Y, Hattori N: Leucine-rich repeat kinase 2 associates with lipid rafts. Hum Mol Genet 2007, 16(6):678-690.

106. Blasius TL, Cai D, Jih GT, Toret CP, Verhey KJ: Two binding partners cooperate to activate the molecular motor Kinesin-1. J Cell Biol 2007, 176(1):11-17.

107. Hsu CH, Chan D, Wolozin B: LRRK2 and the stress response: interaction with MKKs and JNK-interacting proteins. Neurodegener Dis 2010, 7(1-3):68-75.

108. Li Y, Liu W, Oo TF, Wang L, Tang Y, Jackson-Lewis V, Zhou C, Geghman K, Bogdanov M, Przedborski S, et al: Mutant LRRK2(R1441G) BAC transgenic mice recapitulate cardinal features of Parkinson's disease. Nat Neurosci 2009, 12(7):826-828.

109. Melrose HL, Dachsel JC, Behrouz B, Lincoln SJ, Yue M, Hinkle KM, Kent CB, Korvatska E, Taylor JP, Witten L, et al: Impaired dopaminergic neurotransmission and microtubule-associated protein tau alterations in human LRRK2 transgenic mice. Neurobiol Dis 2010, 40(3):503-517.

110. Lin CH, Tsai PI, Wu RM, Chien CT: LRRK2 G2019S mutation induces dendrite degeneration through mislocalization and phosphorylation of tau by recruiting autoactivated GSK3beta. J Neurosci 2010, 30(39):13138-13149.

111. West AB, Moore DJ, Choi C, Andrabi SA, Li X, Dikeman D, Biskup S, Zhang Z, Lim KL, Dawson VL, et al: Parkinson's disease-associated mutations in LRRK2 link enhanced GTP-binding and kinase activities to neuronal toxicity. Hum Mol Genet 2007, 16(2):223-232.

112. Karasewski L, Ferreira A: MAPK signal transduction pathway mediates agrin effects on neurite elongation in cultured hippocampal neurons. J Neurobiol 2003, 55(1):14-24.

113. Titz B, Low T, Komisopoulou E, Chen SS, Rubbi L, Graeber TG: The proximal signaling network of the BCR-ABL1 oncogene shows a modular organization. Oncogene 2010, 29(44):5895-910.

114. Sancho RM, Law BM, Harvey K: Mutations in the LRRK2 Roc-COR tandem domain link Parkinson's disease to Wnt signalling pathways. Hum Mol Genet 2009, 18(20):3955-3968

115. Duka T, Duka V, Joyce JN, Sidhu A: Alpha-Synuclein contributes to GSK3beta-catalyzed Tau phosphorylation in Parkinson's disease models. Faseb J 2009, 23(9):2820-2830.

116. Tanji K, Toki T, Tamo W, Imaizumi T, Matsumiya T, Mori F, Takahashi H, Satoh K, Wakabayashi K: Glycogen synthase kinase-3beta phosphorylates synphilin-1 in vitro. Neuropathology 2003, 23(3):199-202.

117. Bridges D, Moorhead GB: $14-3-3$ proteins: a number of functions for a numbered protein. SCi STKE 2004, 2004(242):re10

118. Xu J, Kao SY, Lee FJ, Song W, Jin LW, Yankner BA: Dopamine-dependent neurotoxicity of alpha-synuclein: a mechanism for selective neurodegeneration in Parkinson disease. Nat Med 2002, 8(6):600-606.

119. Berg D, Riess O, Bornemann A: Specification of 14-3-3 proteins in Lewy bodies. Ann Neurol 2003, 54(1):135.
120. Yacoubian YA, Slone SR, Harrington AJ, Hamamichi S, Schieltz JM, Caldwell KA, Caldwell GA, Standaert DG: Differential neuroprotective effects of 14-3-3 proteins in models of Parkinson's disease. Cell Death Dis 2010, 1:e2.

121. Alegre-Abarrategui J, Christian H, Lufino MM, Mutihac R, Venda LL, Ansorge $\mathrm{O}$, Wade-Martins R: LRRK2 regulates autophagic activity and localizes to specific membrane microdomains in a novel human genomic reporter cellular model. Hum Mol Genet 2009, 18(21):4022-4034.

122. Cuervo AM, Stefanis L, Fredenburg R, Lansbury PT, Sulzer D: Impaired degradation of mutant alpha-synuclein by chaperone-mediated autophagy. Science 2004, 305(5688):1292-1295.

123. Vogiatzi T, Xilouri M, Vekrellis K, Stefanis L: Wild type alpha-synuclein is degraded by chaperone-mediated autophagy and macroautophagy in neuronal cells. J Biol Chem 2008, 283(35):23542-23556.

\section{doi:10.1186/1750-1326-6-6}

Cite this article as: Greggio et al:: Leucine-rich repeat kinase 2 and alpha-synuclein: intersecting pathways in the pathogenesis of Parkinson's disease? Molecular Neurodegeneration 2011 6:6.

\section{Submit your next manuscript to BioMed Central and take full advantage of:}

- Convenient online submission

- Thorough peer review

- No space constraints or color figure charges

- Immediate publication on acceptance

- Inclusion in PubMed, CAS, Scopus and Google Scholar

- Research which is freely available for redistribution

Submit your manuscript at www.biomedcentral.com/submit
C) Biomed Central 